\title{
Correspondence
}

\section{Anaesthesia breathing circuits}

To the Editor:

I read with interest the article "Anaesthesia Breathing Circuits." The figure depicting several anaesthetic breathing systems shows the To and Fro System (letter H) with a "pop-off" valve in the elbow between the fresh gas flow inlet and the soda lime canister.

The mistake of adding a "pop-off" valve in the elbow connector between patient and soda lime canister is repeated in several publications in anaesthesia. ${ }^{1-6}$ In some diagrams $s^{3,6}$ the "pop-off" is placed between the fresh gas flow inlet and the patient, in others ${ }^{1.2 .5}$ between fresh gas flow inlet and soda lime canister, and in one ${ }^{4}$ it is adjacent to the fresh gas flow inlet.

Thus, a similarity of design is suggested with either Mapleson $B$ or $C$ systems by having the canister replace the reservoir tubing in system $B$ or placed between breathing bag and fresh gas flow inlet in system $C$. The opposite could also be conceived: Mapleson B or C systems. could be considered a Waters To and Fro System without the canister. Such analogies probably should not be encouraged but, if desired, the proper system for comparison would be system F (no "pop-off," open-tailed bag). At any rate, the proper function of the To and Fro System requires a closed system, which is incompatible with any of the systems in Mapleson's classification. Furthermore, some illustrations ${ }^{1,4}$ show a tubular extension between canister and patient which would be considered an anathema by Waters who always carefully avoided any additional dead space.

The To and Fro System, as used in the Department of Anaesthesia at the University of Wisconsin under Ralph M. Waters, did not incorporate a "pop-off" valve. The breathing bag had an open tail which was kept closed with a clamp. Escape of flows in excess of basal was achieved by partially opening the tail of the bag, a process which was easily graded by changing the angle at which the clamp was applied. It is easy to conceive how the functional behaviour of the system would be modified if a "pop-off" valve were interposed between the fresh gas flow and the patient, or the canister, rather than having the escape distal to the canister.

Perhaps the mistake originates from the fact that the To and Fro System was never popular in England. I trust that forthcoming editions of the English textbooks of anaesthetics will correct this mistake. American textbooks show the correct design of the system. ${ }^{7-10}$
Those of us fortunate enough to have been Ralph Waters' residents were thoroughly familiar with the proper construction and use of the To and Fro System which payed the way to control of ventilation and modern anaesthesia. Even though the To and Fro System is now a museum piece, present and future generations at least should refer to it as it was properly used in its golden days.

\section{Carlos Parsloe MD \\ Department of Anesthesiology \\ Hospital Samaritano \\ Rua Conselheiro Brotero, 1486 \\ 01232-São Paulu-SP \\ Brasil}

\section{REFERENCES}

1 McIntyre JWR. Anaesthesia breathing circuits. Can Anaesth Soc J 1986; 33: 98-105.

2 Gray TC. Nunn JF, Utting JE. General Anaesthesia. 4th ed. Butterworths, 1980 .

3 Conway $C M$. Anaesthetic Breathing Systems. In: Scientific Foundations of Anaesthesia. 3rd ed. C. Scurr and S. Feldman (Eds). William Heinemann Medical Books Limiled, 1982.

4 Smith $G$, Aitkenhead $A R$. 'Textbook of Anaesthetics. Churchill Livingstone, 1985.

5 Ward CS. Anacsthesia Equipment. Physical Principles and Maintenance. Bailtiare Tindall, 1975.

6 Foster PA. Anaesthetic Breathing Systems. Lectures in Anaesthesiology 1985; 1: 25.

7 Dorsch $J A$, Dorsch SE. Understanding Anesthesia Equipment. Construction, Care and Complications. The Williams \& Wilkins Company, and d, 1984.

8 Fundamentals of Anesthesia. 3rd ed. W.B. Saunders Co., 1954.

9 Eger EI II. Anesthetic Uptake and Action. The Williams \& Wilkins Company, 1974.

10 Miller RD (Ed). Anesthesia. 2nd ed. Churchill Livingstone, 1986.

\section{REPLY}

In 1926 Waters described' a to-and-fro carbon dioxide ab. sorption system in which the fresh gas flow entered the tail of the rebreathing bag and a port for venting and sampling gases was sired on the absorber adjacent to the attachment of the bag. In what seems to be his finat version ${ }^{2}$ the fresh gas flow entered at the elbow berween absorber and patient, the excess gas being vented through the tail of the bag. This is the system 
to which Parsioe refers and it is described correctly in at least two Engiish books. ${ }^{3.4}$

Waters' referred to an earlier to-and-fro carbon dioxide absorption system ${ }^{5}$ but he apparently chose not to include the ether drip feed into the absorber that it incorporated. However, later during World War II ether was a popular anaesthetic and a venting port at the elbow seems to have been added at that time. During induction of anaesthesia this location would have been more convenient than one at the tail of the rebreathing bag and a necessary one if bags with tails were not available. When induction was complete appropriate use could be made of a closed system. The modification can be attributed to Barnett Mallinson. 6.7 Dr. Parsloe does us a service when he reminds us of Waters classic design though the modified version illustrated in my review to which he refers was not atrib. uted to Waters.

J.W.R. McIntyrc MD FRCPC

Department of Anaesthesia

University of Alberta Hospitals

Edmonton, Alberta

T6G 2B7

\section{REFERENCES}

1 Waters RM. Advantages and techniques of carbon dioxide filtration with inhalational anesthetic. Anesth Analg 1926; 5: $160-2$

2 Waters RM. Carbon dioxide absorption from anaesthesia atmospheres. J Proc Roy Soc Med 1936; 30: 11-22.

3 Minnett RJ, Gillies J. Textbook of Anaesthesia. 7th Ed. Edinburgh: Livingstone, 1948

4 Goldman V. Aids to Anaesthesia. 4th Ed. London: Bailliere, Tindall and Cox, 1957.

5 Jackson $D E$. The employment of closed ether anesthesia for ordinary laboratory experiments. J Lab Clin Med 1916; 2: 94-102.

6 Mallinson $F B$. Cut outs for to-and-fro absorbers. Br Mcd J $1941 ; 1: 17-8$

7 Atkinson RS, Rushman GB, Lee JA. A Synopsis of Anaesthesia. 8th Ed. Bristol: John Wright \& Sons, 1977.

\section{Single lever Humphrey A.D.E. low flow universal anaesthetic breathing system}

To The Editor:

I read with interest the recent articles by Humphrey ef $a l^{1,2}$ on the single lever Humphrey A.D.E. breathing systems (parallel and co-axial systens). I commend them on their ingenuity but express some concerns. The prime objectives of any breathing system are that it be safe, simple, economical and convenient. Even the simple Bain system can be incorrectly assembled as pointed out by Humphrey et al. ${ }^{3}$ but undoubtably the possibilities of hooking up any combination system incorrectly are much greater.
The Bain co-axial system can readily be tested by the Pethick test as well as visual inspection prior to its use; this is impossible with a combined system. It should be noted that utilizing flows below those recommended for the Bain system during spontaneous or controlled ventilation leads only to a modest hypercarbia. Humphrey er al. demonstrated this for spontaneous ventilation with a Bain system (Figure 5, p. 703). ${ }^{1}$ The Bain system itself will never lead to hypoxia but in combined systems accidental mechanical ventilation in the "A" mode will lead not only to hypercarbia but severe hypoxia.

When we consider that only approximately 20 per cent of total anaesthetic time is with spontaneous ventilation, the economy and practicality of combined systems becomes much less. The increased cost because of the complexity of the anaesthesia machine adaptor for this system is much greater than a modest increase in fresh gas flow in the Bain system for spontaneous ventilation.

The parallel system (non co-axial) as described has no increased convenience over the circle. The co-axial system with a $28 \mathrm{~mm}$ diameter is bulky, particularly for children and head and neck procedures when compared to the $22 \mathrm{~mm}$ diameter co-axial Bain system that is suitable for all procedures and all age groups.

I would like to make a plea for simplicity. The combination systems add greatly to the complexity of our breathing systems, as pointed out by Conway ${ }^{4}$ and this must be weighed against any disadvantages of the noncombined systems (Magill, Bain, Jackson-Recs or circle systems).

Finally and most importantly, I would like to stress that all anaesthetists must understand fully the breathing system or systems they choose and test them for proper function prior to connection to the patient.

\section{James A. Bain MD FRCPC}

Department of Anaesthesia

University of Western Ontario

London, Ontario

N6A 5A5

\section{REFERENCES}

1 Humphrey D. Brock-Utne JG, Downing JW. Single lever Humphrey A.D.E. low flow universal breathing system. Part I: Comparison with dual lever A.D.E., Magill and Bain systems in andesthetized spontaneously breathing adults. Can Anacsth Soc J 1986; 33: 698-709.

2 Humphrey D, Brock-Utne JG, Downing JW. The single lever Humphrey A.D.E. low flow universal anaesthesia breathing system. Part II: Comparison with Bain System in anaesthetized adults during controlled ventilation. Can Anaesth Soc J 1986; 33; 710-8. 